\title{
Effect of Riboflavin on the Photolysis of Cyanocobolamin in Aqueous Solution
}

\author{
Iqbal Ahmad ${ }^{*}, 1$, Ambreen Hafeez ${ }^{2}$, Naheed Akhter ${ }^{2}$, Faiyaz H. M. Vaid ${ }^{3}$ and Kiran Qadeer ${ }^{1}$ \\ ${ }^{I}$ Institute of Pharmaceutical Sciences, Baqai Medical University, Toll Plaza, Super Highway, Gadap Road, Karachi- \\ 74600, Pakistan \\ ${ }^{2}$ Department of Biochemistry, Biophysics Research Unit, University of Karachi, Karachi-75270, Pakistan \\ ${ }^{3}$ Department of Pharmaceutical Chemistry, Faculty of Pharmacy, University of Karachi, Karachi-75270, Pakistan
}

\begin{abstract}
The kinetics of photolysis of cyanocobalamin (CC) by visible radiation in the presence of riboflavin ( $\mathrm{RF})$ at $\mathrm{pH}$ 2.0-12.0 has been studied. A specific two-component spectrophotometric method has been used for the simultaneous assay of CC and its photoproduct, hydroxocobalamin (HC), at 525 and $550 \mathrm{~nm}$, without any interference from RF. The apparent first-order rate constants for the photolysis of $\mathrm{CC}$ in the presence of $1-5 \times 10^{-5} \mathrm{M}$ concentrations of $\mathrm{RF}$ at $\mathrm{pH} 2.0$ 12.0 range from $0.46(\mathrm{pH} 7.0)$ to $4.22 \times 10^{-3} \mathrm{~min}^{-1}(\mathrm{pH} 3.5)$. The second-order rate constants for the bimolecular interaction of these vitamins are in the range of $8.66(\mathrm{pH} 7.5)$ to $45.20 \mathrm{M}^{-1} \mathrm{~min}^{-1}(\mathrm{pH} 2.0)$. The rate-pH profile indicates a gradual decrease in rate in the acid $\mathrm{pH}$ range followed by the slowest rate and maximum stability around $\mathrm{pH} 7-8$. Thus the cationic form of CC is more susceptible to photolysis compared to the neutral form. The increase in rate in the alkaline region is probably due to the hydrolysis of the amide groups. The kinetic results indicate that RF acts as a sensitizer in the photolysis of $\mathrm{CC}$ and in this way promotes the degradation of the molecule. Thus the presence of RF in CC solutions adversely affects the stability of vitamin $\mathrm{B}_{12}$.
\end{abstract}

Keywords: Cyanocobalamin, riboflavin, photolysis, kinetics, interaction.

\section{INTRODUCTION}

Cyanocobalamin (Vitamin $\mathrm{B}_{12}$ ) is used in the treatment of pernicious anemia [1]. The chemical and biochemical aspects $[2,3]$, and stability and interactions [4-9] of cyanocobalamin have been reviewed. It is sensitive to light [10-12] and on photodegradation in aqueous solution [4, 13-17] and dietary supplements [18] is converted to hydroxocobalamin and further products [4, 13-17]. Riboflavin [19, 20] and nicotinamide [21] enhance the photodegradation of cyanocobalamin. The present work is based on a kinetic study of the effect of riboflavin on the photodegradation of cyanocobalamin over a wide range of $\mathrm{pH}$ using a specific twocomponent spectrophotometric method [16]. Similar studies of the effect of riboflavin on the photodegradation of folic acid [22] and other compounds [23] have been reported. The information may facilitate the understanding of the interaction and stabilization of cyanocobalamin in pharmaceutical preparations on exposure to light. The chemical structures of riboflavin, cyanocobal-amin and hydroxocobalamin are shown in Fig. (1).

\section{MATERIALS AND METHODS}

Cyanocobalamin (CC) and hydroxocobalamin (HC) were obtained from Fluka (Switzerland). Riboflavin (RF), lumichrome (LC) and lumiflavin (LF) were obtained from Sigma Chemical Co. (USA). Formylmethylflavin (FMF) and

*Address correspondence to this author at the Institute of Pharmaceutical Sciences, Baqai Medical University, Toll Plaza, Super Highway, Gadap Road, Karachi-74600, Pakistan; Tel: +92-21-34410293; Fax: +92-2134410317; E-mail: dr_i_a@hotmail.com carboxymethylflavin (CMF) were prepared by the methods of Fall and Petering [24] and Fukumachi and Sakurai [25], respectively. Thin- layer chromatography (TLC) was used to confirm the purity of these compounds. All reagents and solvents were analytical grade or of the purest form available from Merck/BDH. The following buffer systems were used throughout. $\mathrm{HCl}-\mathrm{KCl}, \mathrm{pH} 2.0$; citric acid- $\mathrm{Na}_{2} \mathrm{HPO}_{4}, \mathrm{pH} 2.5$ 8.0; $\mathrm{Na}_{2} \mathrm{~B}_{4} \mathrm{O}_{7}-\mathrm{HCl}, \mathrm{pH}$ 8.5-9.0; $\mathrm{Na}_{2} \mathrm{~B}_{4} \mathrm{O}_{7}-\mathrm{NaOH}, 9.5-10.5$; $\mathrm{Na}_{2} \mathrm{HPO}_{4}-\mathrm{NaOH}, 11.0-12.0$; the ionic strength was $0.02 \mathrm{M}$ in each case.

\section{Precautions}

The experimental work was carried out in a dark chamber under subdued light. Freshly prepared aqueous solutions of $\mathrm{CC}$ and RF were used for each experiment. All the solutions were protected from light before irradiation to avoid any chemical or photochemical effects.

\section{Photolysis}

A series of $5 \times 10^{-5} \mathrm{M}$ aqueous solutions of $\mathrm{CC}$ containing $1.0-5.0 \times 10^{-5} \mathrm{M} \mathrm{RF}$ at the appropriate $\mathrm{pH}$ were prepared in 100 $\mathrm{ml}$ volumetric flasks (Pyrex) and placed in a water bath maintained at $25 \pm 1{ }^{\circ} \mathrm{C}$ in a radiation chamber. The solutions were irradiated with a Philips HPLN $125 \mathrm{~W}$ high pressure mercury vapor florescent lamp (emission at 405, 436, 540 and $577 \mathrm{~nm}$ ), fixed horizontally at a distance of $30 \mathrm{~cm}$ from the centre of the flasks. The major emission wavelengths of the irradiation source correspond to the absorption maxima of $\mathrm{CC}$ $(550 \mathrm{~nm})$ and RF $(444 \mathrm{~nm})$ in the visible region [26]. The solution was continuously bubbled with a gentle stream of air. Samples were withdrawn at appropriate intervals for thin-layer chromatography and spectrophotometric assay. 
<smiles>Cc1cc2nc3c(=O)[nH]c(=O)nc-3n(C[C@H](O)[C@H](O)[C@H](O)CO)c2cc1C</smiles>

(1)

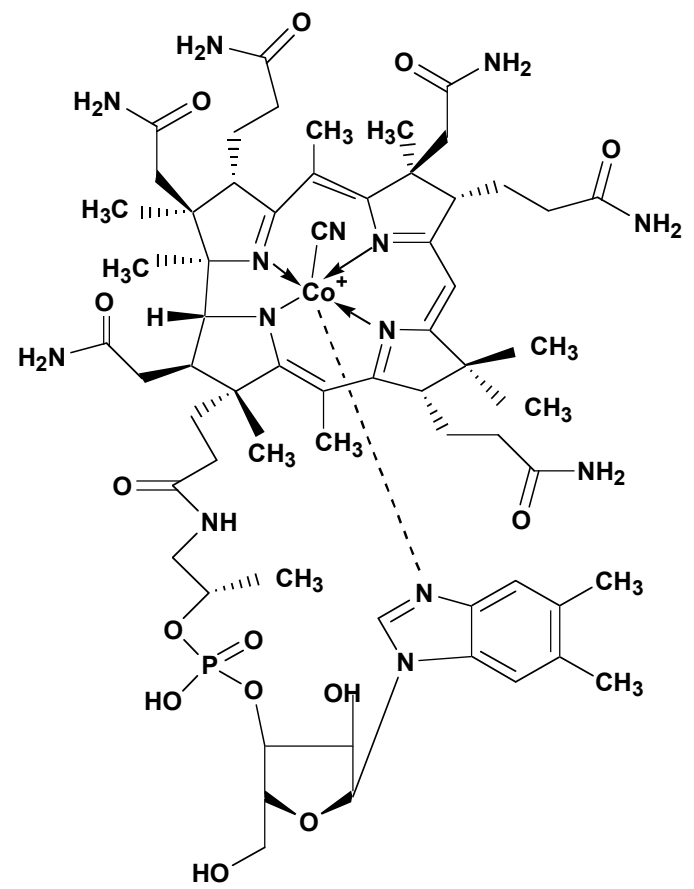

(2)

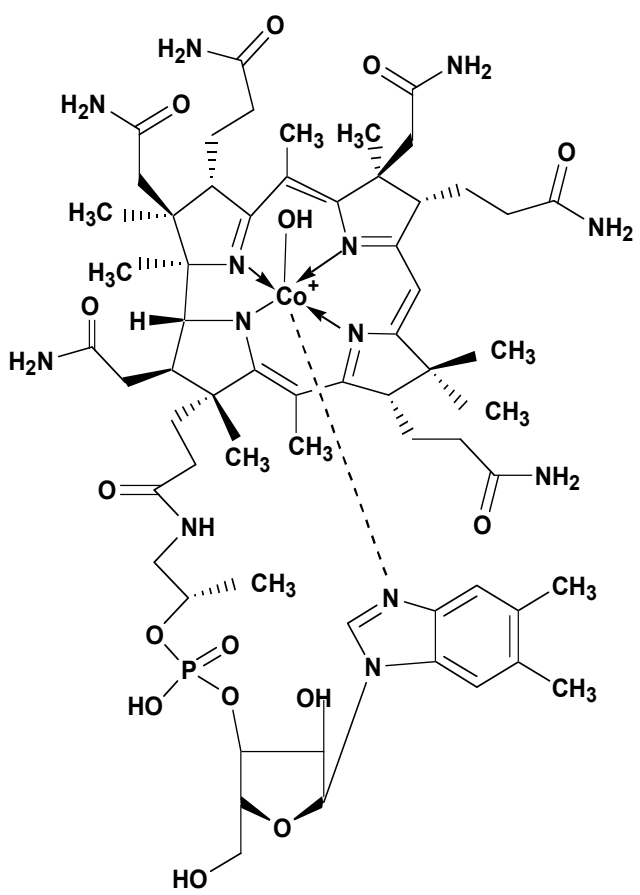

(3)

Fig. (1). Chemical structures of riboflavin (1), cyanocobalamin (2) and hydroxocobalamin (3).

\section{Thin-Layer Chromatography (TLC)}

TLC of the photolysed solutions of CC was carried out to detect the photoproducts of $\mathrm{CC}$ and $\mathrm{RF}$ by using the following systems:

CC: $250-\mu \mathrm{m}$ silica gel $\mathrm{GF}_{254}$ plates using the solvent systems: (A) 1-butanol-acetic acid-0.066 $\mathrm{M}$ potassium dihydrogen phosphate-methanol (36:18:36:10, v/v) [27]; and (B) methanol-water $(95: 5, \mathrm{v} / \mathrm{v})$ [28]. The spots were located visually (red colour) or under UV-light.

RF: $250-\mu \mathrm{m}$ cellulose plates (Whatman CC 41) using the solvent systems: (C) 1-butanol-acetic acid-water (40:10:50, $\mathrm{v} / \mathrm{v}$, organic phase); and (D) 1-butanol-1-propanol-acetic acid-water (50:30:2:18, v/v) [29]. The compounds were detected by their characteristic florescence emission under UV (365 nm) excitation.

\section{Spectral Measurements}

All spectral measurements on RF, CC and their photolysed solutions were carried out on a Shimadzu UV240 recording spectrophotometer using silica cells of $10 \mathrm{~mm}$ path length.

\section{Light Intensity Measurements}

The intensity of the Philips HPLN $125 \mathrm{~W}$ high pressure mercury vapor fluorescent lamp was determined by potassium ferrioxalate actinometry [30] as 1.17 $\pm 0.10 \times 10^{17}$ quanta $\mathrm{s}^{-1}$.

\section{Assay Method}

The assay of $\mathrm{CC}$ and its photoproduct, $\mathrm{HC}$, in degraded solutions was carried out using a two-component spectrophotometric method of Ahmad et al. [16] by the

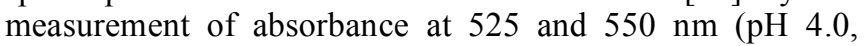
acetate buffer). The method was validated in the presence of RF to ensure its accuracy and specificity. The reproducibility of the method was determined by the analysis of synthetic mixtures of $\mathrm{CC}$ and $\mathrm{HC}$ in the presence of the highest concentration of $\mathrm{RF}\left(5 \times 10^{-5} \mathrm{M}\right)$ used in the reactions.

\section{RESULTS AND DISCUSSION}

\section{Photoproducts of $\mathrm{CC}$ and $\mathrm{RF}$}

TLC of the solutions of CC photolysed in the presence of RF using solvents systems (A) and (B) showed HC as the only products of its photolysis at all $\mathrm{pH}$ values. This product is formed by the cleavage of $\mathrm{Co}^{3+}-\mathrm{CN}$ bond [31] as follows: 


$$
\begin{aligned}
& {\left[\mathrm{Co}^{3+}-\mathrm{CN}\right]} \\
& \mathrm{CC} \\
& \stackrel{h v}{\longrightarrow} \underset{\mathrm{HC}}{\left[\mathrm{Co}^{3+} \mathrm{OH}\right]+\mathrm{CN}^{-}}
\end{aligned}
$$

The photolysed solutions of $\mathrm{CC}$ were also subjected to TLC using the solvent systems (C) and (D), and FMF, LC and CMF (acidic solutions) and FMF, LC, LF and CMF (neutral and alkaline solutions) were detected as the photoproducts of RF. All the photoproducts were identified by comparison of the $\mathrm{R}_{f}$ values and colour/ fluorescence of the spots with those of the authentic compounds (Table 1).

\section{Assay of CC and $\mathrm{HC}$ in Photolysed Solutions}

$\mathrm{CC}$ and $\mathrm{HC}$ exhibit absorption maxima at 361 and $550 \mathrm{~nm}$, and 351 and $525 \mathrm{~nm}$, respectively, in aqueous solution [26]. A two-component spectrophotometric method has been reported for the assay of CC and $\mathrm{HC}$ at 351 and 361 or 525 and $550 \mathrm{~nm}(\mathrm{pH} \mathrm{4.0)}$ in photolysed solutions. RF absorbs at 223, 267, 374 and $444 \mathrm{~nm} \mathrm{[10]} \mathrm{and} \mathrm{would}$ interfere with the assay of $\mathrm{CC}$ and $\mathrm{HC}$ at 351 and $361 \mathrm{~nm}$. It has negligible absorbance beyond $500 \mathrm{~nm}$ and, therefore, to compensate for any absorbance contribution at $525 \mathrm{~nm}$, an equivalent amount of RF was used as a blank. The degradation products of RF do not absorb in the region of analytical wave lengths. The method has been validated in the presence of RF and the results of the assay of synthetic mixtures of $\mathrm{CC}$ and $\mathrm{HC}$ in the concentration range likely to occur in the photolysed solution are given in Table 2. The values of RSD are within $\pm 3 \%$ which show that the method is accurate and reliable for the assay of $\mathrm{CC}$ and $\mathrm{HC}$ in photolysed solutions in the presence of RF. The results of the assay of $\mathrm{CC}$ and $\mathrm{HC}$ in a photolysis reaction carried out at $\mathrm{pH} 4.0$ are given in Table 3. The data show decreasing concentrations of $\mathrm{CC}$ and increasing concentrations of $\mathrm{HC}$, with time, giving a constant molar balance.

\section{Kinetics of Photolysis}

The kinetics of photolysis of $\mathrm{CC}$ in the presence of RF has been studied in the $\mathrm{pH}$ range of 2.0-12.0. The apparent first-order rate constants $\left(k_{\mathrm{obs}}\right)$ for the photolysis reactions at various concentrations of $\mathrm{RF}$ are reported in Table 4 . These rate constants were determined by linear regression analysis and the values of correlation coefficients were obtained in the range of 0.995-0.999. The results show that RF promotes the degradation of $\mathrm{CC}$ on exposure to light and the rate increases with an increase in RF concentration throughout the $\mathrm{pH}$ range. The second-order rate constants $\left(k^{\prime}\right)$ for the bimolecular interaction of CC and RF and the values of $\left(k_{0}\right)$ ( $k_{\mathrm{obs}}$ in the absence of RF) are reported in Table 5. The $k^{\prime}$ values range from $8.66(\mathrm{pH} 7.5)$ to $45.20 \mathrm{M}^{-1} \min ^{-1}$ ( $\mathrm{pH} 2.0$ ) indicating a greater interaction in the acid medium. The values of $k_{0}$ are about one-half of the values of $k_{\text {obs }}$ for CC at the highest concentration of RF $\left(5 \times 10^{-5} \mathrm{M}\right)$ indicating that the rate of photolysis is enhanced in the presence of RF. The $\mathrm{UV}$ and visible absorption spectra of RF and CC exist in the $200-600 \mathrm{~nm}$ region. The 278 and $361 \mathrm{~nm}$ absorption maxima of CC overlap the 267 and $444 \mathrm{~nm}$ absorption maxima of

Table 1. $\quad \mathbf{R}_{f}$ Values of CC, RF and Photoproducts

\begin{tabular}{|c|c|c|c|c|c|c|}
\hline Solvent Systems & A & B & C & D & Colour of Spot & Fluorescence $\boldsymbol{\lambda}_{\text {ex }} \mathbf{3 6 5} \mathbf{~ n m}$ \\
\hline \hline Cyanocobalamin & 0.46 & 0.42 & & & Red & Red \\
\hline Hydroxocobalamin & 0.25 & 0.05 & & & Yellow green \\
\hline Riboflavin & & & 0.47 & 0.27 & Yellow green \\
\hline Formylmethylflavin & & & 0.20 & 0.70 & & Sky blue \\
\hline Lumichrome & & & 0.66 & 0.63 & & Yellow green \\
\hline Lumiflavin & & & 0.53 & 0.41 & & Yellow green \\
\hline Carboxymethyflavin & & & 0.28 & 0.20 & & \\
\hline
\end{tabular}

Table 2. Spectrophotometric Assay of CC and HC in Synthetic Mixtures in the Presence of RF

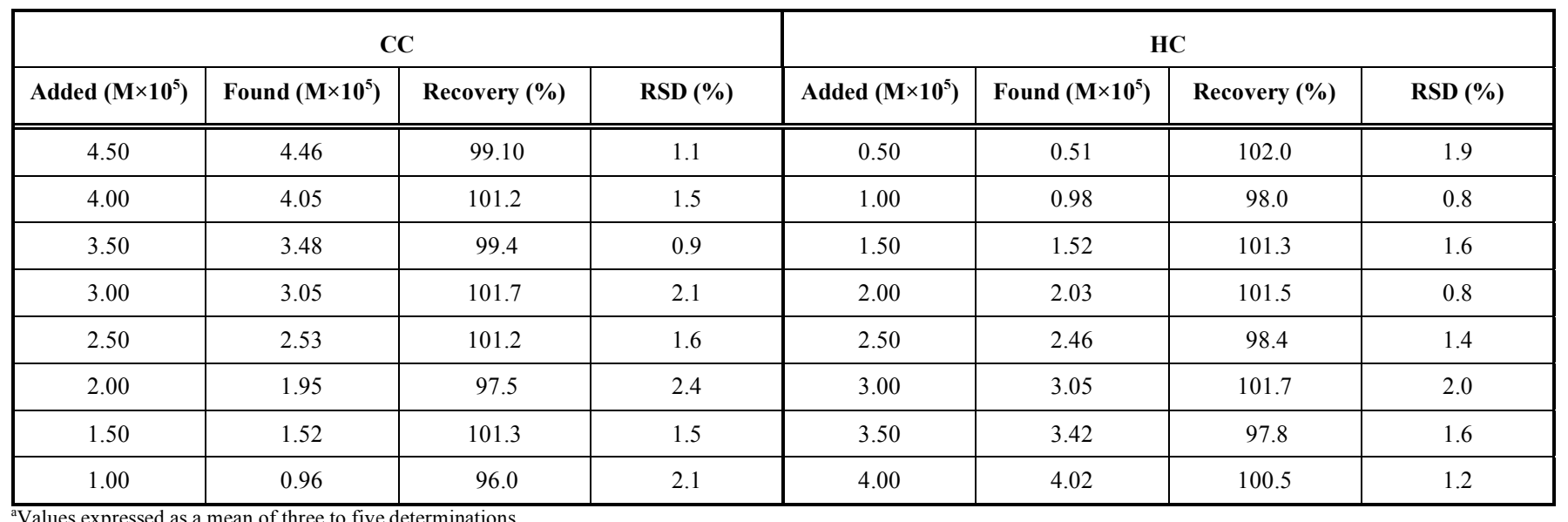


RF. Therefore, there is strong possibility of mutual interaction and energy transfer from RF in the excited state to $\mathrm{CC}$ resulting in its degradation. Such an energy transfer between molecules has been suggested by Moore [32]. The spectral variations during the photolysis of $\mathrm{CC}$ in the presence of RF have been studied by Ansari et al. [33].

Table 3. Photolysis of a $5 \times 10^{-5} \mathrm{M}$ Solution of $\mathrm{CC}$ in the Presence of $5 \times 10^{-5} \mathrm{M}$ RF at $\mathrm{pH} 4.0$

\begin{tabular}{|c|c|c|c|}
\hline Time (min) & $\mathbf{C C}\left(\mathbf{M} \times \mathbf{1 0}^{\mathbf{5}}\right)$ & $\mathbf{H C}\left(\mathbf{M} \times \mathbf{1 0}^{\mathbf{5}}\right)$ & Total $\left(\mathbf{M} \times \mathbf{1 0}^{\mathbf{5}}\right)$ \\
\hline \hline 0 & 5.00 & - & 5.00 \\
\hline 60 & 4.03 & 0.95 & 4.98 \\
\hline 120 & 3.38 & 1.64 & 5.02 \\
\hline 180 & 2.75 & 2.21 & 4.96 \\
\hline 240 & 2.28 & 2.70 & 4.98 \\
\hline 300 & 1.99 & 2.97 & 4.96 \\
\hline
\end{tabular}

\section{Rate-pH Profile}

The $k^{\prime}-\mathrm{pH}$ profile for the photolysis of $\mathrm{CC}$ in the presence of RF is shown in Fig. (2). It represents a broad V shaped curve involving different species of the molecule $\left(\mathrm{B}_{12}\right)$ that undergo photodegradation. The value of $k_{\mathrm{obs}}$ for the degradation of $\mathrm{CC}$ is the sum of the rate constants for specific acid-catalyzed, water-catalyzed and specific basedcatalyzed reactions occurring in different regions.

$k_{\mathrm{obs}}=k_{\mathrm{H}}^{+}\left[\mathrm{B}_{12} \mathrm{H}^{+}\right]+k_{\mathrm{H}_{2} \mathrm{O}}\left[\mathrm{B}_{12}\right]+k_{\mathrm{OH}}{ }^{-}\left[\mathrm{B}_{12}\right]$

where $k_{\mathrm{H}}{ }^{+}, k_{\mathrm{H} 2 \mathrm{O}}$ and $k_{\mathrm{OH}}{ }^{-}$are the rate constants for the hydrogen ion-catalyzed, water-catalyzed, hydroxide ioncatalyzed reactions, respectively.

The gradual decrease in the rate in the $\mathrm{pH}$ range 2-6 is the acid-catalyzed photolysis of protonated $\mathrm{CC}(\mathrm{pKa} 3.3$ ) [34], followed by a small plateau of water-catalyzed reaction (6.5-8.5) in which the rate is almost independent of $\mathrm{pH}$. In the $\mathrm{pH}$ range of 9-12 the increase in rate is due to the hydrolysis of amide groups [8]. The maximum stability of $\mathrm{CC}$ in light occurs on the degradation of the neutral molecule around $\mathrm{pH}$ 7-8. A somewhat similar profile for the photolysis of CC alone has been observed by Ahmed et al. [16]. This type of profiles has also been reported for the specific acidbase catalyzed degradation of acetaminophen, cefotaxime, indomethacin, methicillin, and phenethicillin [8].

\section{Photochemical Interaction of CC and RF}

The basic reactions in the photolysis of $\mathrm{CC}$ have been explained in the above section. The photolysis of $\mathrm{CC}$ in the presence of RF involves photochemical interaction of the two molecules (given by the second-order rate constant, $k^{\prime}$ ). The $k^{\prime}$-pH profile (Fig. 2) represents photodegradation of CC in the presence of RF. In this reaction RF appears to play the role of a photosensitizer as observed for such reactions $[23,32]$ and this can be expressed by the following equations.

${ }^{0} \mathrm{RF} \longrightarrow \stackrel{h v}{\longrightarrow}{ }^{1} \mathrm{RF}$

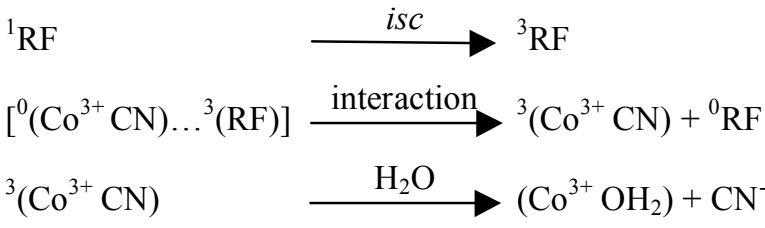

Table 4. First-Order Rate Constants $\left(k_{\text {obs }}\right)$ for the Photolysis of $\mathrm{CC}$ in the Presence of RF (1.0-5.0 $\left.\times 10^{-5} \mathrm{M}\right)$

\begin{tabular}{|c|c|c|c|c|c|}
\hline \multirow{2}{*}{ pH } & \multicolumn{5}{|c|}{$k_{\mathrm{obs}} \times 10^{3} \mathrm{~min}^{-1}$} \\
\hline & $1.0^{\mathrm{a}}$ & $2.0^{a}$ & $3.0^{\mathrm{a}}$ & $4.0^{\mathrm{a}}$ & $5.0^{\mathrm{a}}$ \\
\hline 2.0 & $\begin{array}{c}2.26 \\
(0.998)\end{array}$ & $\begin{array}{c}2.75 \\
(0.996)\end{array}$ & $\begin{array}{c}3.15 \\
(0.997)\end{array}$ & $\begin{array}{c}3.59 \\
(0.998)\end{array}$ & $\begin{array}{c}4.10 \\
(0.995)\end{array}$ \\
\hline 2.5 & $\begin{array}{c}2.25 \\
(0.996)\end{array}$ & $\begin{array}{c}2.65 \\
(0.997)\end{array}$ & $\begin{array}{c}3.01 \\
(0.995)\end{array}$ & $\begin{array}{c}3.50 \\
(0.997)\end{array}$ & $\begin{array}{c}3.79 \\
(0.998)\end{array}$ \\
\hline 3.0 & $\begin{array}{c}2.48 \\
(0.997)\end{array}$ & $\begin{array}{c}2.88 \\
(0.995)\end{array}$ & $\begin{array}{c}3.22 \\
(0.997)\end{array}$ & $\begin{array}{c}3.57 \\
(0.995)\end{array}$ & $\begin{array}{c}3.88 \\
(0.998)\end{array}$ \\
\hline 3.5 & $\begin{array}{c}3.02 \\
(0.997)\end{array}$ & $\begin{array}{c}3.28 \\
(0.995)\end{array}$ & $\begin{array}{c}3.62 \\
(0.996)\end{array}$ & $\begin{array}{c}3.95 \\
(0.998)\end{array}$ & $\begin{array}{c}4.22 \\
(0.996)\end{array}$ \\
\hline 4.0 & $\begin{array}{c}2.16 \\
(0.998)\end{array}$ & $\begin{array}{c}2.45 \\
(0.995)\end{array}$ & $\begin{array}{c}2.71 \\
(0.997)\end{array}$ & $\begin{array}{c}2.92 \\
(0.996)\end{array}$ & $\begin{array}{c}3.18 \\
(0.999)\end{array}$ \\
\hline 4.5 & $\begin{array}{c}3.31 \\
(0.996)\end{array}$ & $\begin{array}{c}3.50 \\
(0.996)\end{array}$ & $\begin{array}{c}3.76 \\
(0.997)\end{array}$ & $\begin{array}{c}3.93 \\
(0.995)\end{array}$ & $\begin{array}{c}4.14 \\
(0.996)\end{array}$ \\
\hline 5.0 & $\begin{array}{c}3.52 \\
(0.996)\end{array}$ & $\begin{array}{c}3.69 \\
(0.997)\end{array}$ & $\begin{array}{c}3.91 \\
(0.997)\end{array}$ & $\begin{array}{c}4.06 \\
(0.996)\end{array}$ & $\begin{array}{c}4.21 \\
(0.998)\end{array}$ \\
\hline 5.5 & $\begin{array}{c}3.48 \\
(0.996)\end{array}$ & $\begin{array}{c}3.67 \\
(0.997)\end{array}$ & $\begin{array}{c}3.79 \\
(0.998)\end{array}$ & $\begin{array}{c}3.99 \\
(0.997)\end{array}$ & $\begin{array}{c}4.15 \\
(0.996)\end{array}$ \\
\hline 6.0 & $\begin{array}{c}1.59 \\
(0.995)\end{array}$ & $\begin{array}{c}1.70 \\
(0.995)\end{array}$ & $\begin{array}{c}1.85 \\
(0.997)\end{array}$ & $\begin{array}{c}1.97 \\
(0.996)\end{array}$ & $\begin{array}{c}2.10 \\
(0.998)\end{array}$ \\
\hline 6.5 & $\begin{array}{c}0.58 \\
(0.995)\end{array}$ & $\begin{array}{c}0.70 \\
(0.997)\end{array}$ & $\begin{array}{c}0.83 \\
(0.996)\end{array}$ & $\begin{array}{c}0.92 \\
(0.995)\end{array}$ & $\begin{array}{c}1.05 \\
(0.997)\end{array}$ \\
\hline 7.0 & $\begin{array}{c}0.46 \\
(0.995)\end{array}$ & $\begin{array}{c}0.56 \\
(0.996)\end{array}$ & $\begin{array}{c}0.66 \\
(0.995)\end{array}$ & $\begin{array}{c}0.73 \\
(0.996)\end{array}$ & $\begin{array}{c}0.84 \\
(0.997)\end{array}$ \\
\hline 7.5 & $\begin{array}{c}0.77 \\
(0.995)\end{array}$ & $\begin{array}{c}0.86 \\
(0.997)\end{array}$ & $\begin{array}{c}0.92 \\
(0.997)\end{array}$ & $\begin{array}{c}1.02 \\
(0.995)\end{array}$ & $\begin{array}{c}1.12 \\
(0.996)\end{array}$ \\
\hline 8.0 & $\begin{array}{c}0.73 \\
(0.995)\end{array}$ & $\begin{array}{c}0.81 \\
(0.996)\end{array}$ & $\begin{array}{c}0.90 \\
(0.997)\end{array}$ & $\begin{array}{c}0.97 \\
(0.996)\end{array}$ & $\begin{array}{c}1.08 \\
(0.995)\end{array}$ \\
\hline 8.5 & $\begin{array}{c}0.87 \\
(0.995)\end{array}$ & $\begin{array}{c}0.94 \\
(0.996)\end{array}$ & $\begin{array}{c}1.04 \\
(0.999)\end{array}$ & $\begin{array}{c}1.12 \\
(0.995)\end{array}$ & $\begin{array}{c}1.21 \\
(0.996)\end{array}$ \\
\hline 9.0 & $\begin{array}{c}0.58 \\
(0.997)\end{array}$ & $\begin{array}{c}0.68 \\
(0.998)\end{array}$ & $\begin{array}{c}0.81 \\
(0.995)\end{array}$ & $\begin{array}{c}0.92 \\
(0.996)\end{array}$ & $\begin{array}{c}1.02 \\
(0.995)\end{array}$ \\
\hline 9.5 & $\begin{array}{c}0.77 \\
(0.999)\end{array}$ & $\begin{array}{c}0.84 \\
(0.996)\end{array}$ & $\begin{array}{c}1.04 \\
(0.995)\end{array}$ & $\begin{array}{c}1.15 \\
(0.997)\end{array}$ & $\begin{array}{c}1.27 \\
(0.996)\end{array}$ \\
\hline 10.0 & $\begin{array}{c}1.43 \\
(0.995)\end{array}$ & $\begin{array}{c}1.55 \\
(0.996)\end{array}$ & $\begin{array}{c}1.68 \\
(0.997)\end{array}$ & $\begin{array}{c}1.84 \\
(0.996)\end{array}$ & $\begin{array}{c}1.99 \\
(0.998)\end{array}$ \\
\hline 10.5 & $\begin{array}{c}1.53 \\
(0.995)\end{array}$ & $\begin{array}{c}1.70 \\
(0.998)\end{array}$ & $\begin{array}{c}1.84 \\
(0.997)\end{array}$ & $\begin{array}{c}1.99 \\
(0.995)\end{array}$ & $\begin{array}{c}2.20 \\
(0.996)\end{array}$ \\
\hline 11.0 & $\begin{array}{c}0.65 \\
(0.996)\end{array}$ & $\begin{array}{c}0.81 \\
(0.997)\end{array}$ & $\begin{array}{c}1.02 \\
(0.995)\end{array}$ & $\begin{array}{c}1.27 \\
(0.998)\end{array}$ & $\begin{array}{c}1.39 \\
(0.995)\end{array}$ \\
\hline 11.5 & $\begin{array}{c}1.52 \\
(0.996)\end{array}$ & $\begin{array}{c}1.76 \\
(0.995)\end{array}$ & $\begin{array}{c}1.92 \\
(0.999)\end{array}$ & $\begin{array}{c}2.14 \\
(0.995)\end{array}$ & $\begin{array}{c}2.38 \\
(0.997)\end{array}$ \\
\hline 12.0 & $\begin{array}{c}1.54 \\
(0.996)\end{array}$ & $\begin{array}{c}1.73 \\
(0.995)\end{array}$ & $\begin{array}{c}1.96 \\
(0.995)\end{array}$ & $\begin{array}{c}2.17 \\
(0.996)\end{array}$ & $\begin{array}{c}2.43 \\
(0.997)\end{array}$ \\
\hline
\end{tabular}


The ground state RF $\left({ }^{0} \mathrm{RF}\right)$ is promoted to the excited singlet state $\left({ }^{1} \mathrm{RF}\right)$ by the absorption of a quantum of light (2) and may be converted to the excited triplet state $\left({ }^{3} \mathrm{RF}\right)$ by intersystem crossing (isc) (3). The ground state $\mathrm{CC}\left[^{0}\left(\mathrm{Co}^{3+}\right.\right.$ $\mathrm{CN})$ ] may react with ${ }^{3} \mathrm{RF}$ to form a transient excited state complex (exciplex) as suggested by Sunshine [34] and Moore [32]. This complex may lead to the formation of the excited triplet state of $\left.\mathrm{CC}^{3}\left(\mathrm{Co}^{3+} \mathrm{CN}\right)\right]$ and ground state $\mathrm{RF}$ $\left({ }^{0} \mathrm{RF}\right)(4) .{ }^{3}\left(\mathrm{Co}^{3+} \mathrm{CN}\right)$ is degraded to $\mathrm{HC}\left(\mathrm{Co}^{3+} \mathrm{OH}_{2}\right)$ and $\mathrm{CN}^{-}$ in the presence of water (5). Thus, the role of RF in the photolysis of $\mathrm{CC}$ is to enhance the reaction and this is evident from the fact that an increase in RF concentration results in an increase in the rate of the reaction (Table 4). Since RF ( $\mathrm{pKa}_{1} 1.9, \mathrm{pKa}_{2}$ 10.2) [35] also exists in different ionized states in the $\mathrm{pH}$ range $2.0-12.0$, the reaction between $\mathrm{CC}$ and RF and the rate of photolysis would depend on the ionized states of the two molecules and their susceptibility to photochemical interaction in a particular $\mathrm{pH}$ range. This could be observed from the shape of the $k^{\prime}-\mathrm{pH}$ profile for the photolysis reactions of CC.

Table 5. First-Order Rate Constants $\left(k_{0}\right)$ for the Photolysis of CC in the Absence of RF and Second-Order Rate Constant for the Photolysis of $\mathrm{CC}\left(k^{\prime}\right)$ in the Presence of $\mathbf{R F}^{\mathrm{a}}$

\begin{tabular}{|c|c|c|c|}
\hline pH & $k_{0} \times 10^{3}\left(\min ^{-1}\right)$ & $k^{\prime}\left(\mathbf{M}^{-1} \min ^{-1}\right)$ & Correlation Coefficient \\
\hline 2.0 & 1.81 & 45.20 & 0.998 \\
\hline 2.5 & 1.86 & 39.30 & 0.995 \\
\hline 3.0 & 2.16 & 34.90 & 0.998 \\
\hline 3.5 & 2.70 & 30.69 & 0.997 \\
\hline 4.0 & 1.93 & 25.11 & 0.997 \\
\hline 4.5 & 3.10 & 20.90 & 0.996 \\
\hline 5.0 & 3.35 & 17.71 & 0.995 \\
\hline 5.5 & 3.32 & 16.60 & 0.996 \\
\hline 6.0 & 1.46 & 12.89 & 0.998 \\
\hline 6.5 & 0.47 & 11.62 & 0.997 \\
\hline 7.0 & 0.37 & 9.31 & 0.998 \\
\hline 7.5 & 0.68 & 8.68 & 0.996 \\
\hline 8.0 & 0.64 & 8.66 & 0.995 \\
\hline 8.5 & 0.77 & 8.74 & 0.996 \\
\hline 9.0 & 0.46 & 11.29 & 0.998 \\
\hline 9.5 & 0.62 & 13.07 & 0.999 \\
\hline 10.0 & 1.27 & 14.17 & 0.998 \\
\hline 10.5 & 1.37 & 16.28 & 0.996 \\
\hline 11.0 & 0.45 & 19.42 & 0.997 \\
\hline 11.5 & 1.32 & 20.91 & 0.996 \\
\hline 12.0 & 1.30 & 22.14 & 0.997 \\
\hline
\end{tabular}
conditions including the light intensity.

\section{Pharmaceutical Implications}

Vitamins are often formulated in combination in B complex and multivitamin preparations. These preparations contain both RF and $\mathrm{CC}$ which may interact in light leading to the loss of the later vitamin. The photochemical interaction of these vitamin is minimum in the $\mathrm{pH}$ range around 7-8 and, therefore, this range is suitable for imparting optimum stability to $\mathrm{CC}$ in liquid vitamin preparations. A consideration of the stability of other vitamins in these preparations, in addition to $\mathrm{RF}$ and $\mathrm{CC}$, would help to achieve a better formulation with prolonged shelf-life.

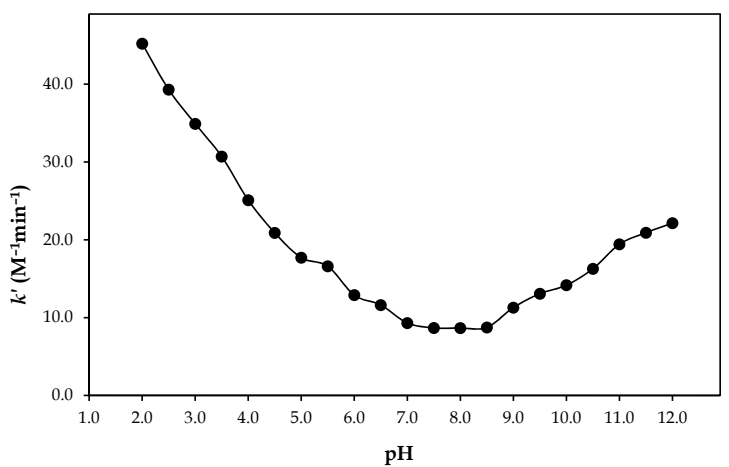

Fig. (2). $k^{\prime}$-pH profile for the photolysis of cyanocobalamin in the presence of riboflavin.

\section{CONCLUSION}

The photolysis of cyanocobalamin in aqueous solution is promoted by riboflavin. This may probably result from their mutual interaction in the excited state followed by energy transfer from riboflavin to cyanocobalamin and its enhanced degradation. The photolysis of cyanocobalamin in aqueous solution is affected by the ionization of the molecule and is greater in the acidic medium compared to that of the neutral solution. The rate of photolysis of cyanocobalamin in the presence of the highest concentration of riboflavin at $\mathrm{pH} 7.0$ is more than double compared to that observed in its absence. The higher stability of cyanocobalamin around $\mathrm{pH}$ 7.0 suggests that this region is suitable for maintaining the $\mathrm{pH}$ of vitamin preparations containing cyanocobalamin and riboflavin.

\section{ACKNOWLEDGEMENT}

Declared none.

\section{CONFLICT OF INTEREST}

The authors confirm that this article content has no conflicts of interest.

\section{REFERENCES}

[1] Green, R.; Miller, J.W. Chap. 13. In: Handbook of Vitamins; Zemplini, J.W.; Rucker, R.B.; McCormick, D.B.; Suttie, J.W., Eds. $4^{\text {th }}$ ed.; CRC Press: Boca Raton, FL, 2007.

[2] Banerjee, R. Chemistry and Biochemistry of $B_{12}$, Wiley \& Sons: New York, 1999.

[3] Banerjee, R.; Ragsdale, S.W. The many faces of vitamin $\mathrm{B}_{12}$ catalysis by cobalamin-dependent enzymes. Am. Rev. Biochem., 2003, 72, 209-247.

[4] Macek, T.J. Stability problems with some vitamins in pharmaceuticals, Am. J. Pharm., 1960,132, 433-455.

[5] Lintner, C.J. In: Quality Control in the Pharmaceutical Industry; Cooper, M.S. Ed.; Academic Press: New York, 1973; Vol. 2, pp. 191-192.

[6] Kirschbaum, I. Analytical profiles of Drug Substances; In: Florey, K. Ed.; Academic Press: New York, 1981, Vol.10. pp 183-288.

[7] DeRitter, E. Vitamins in pharmaceutical formulations. J. Pharm. Sci., 1982, 71, 1073-1096.

[8] Connors, K.A.; Amidon, G.L.; Stella, V.J. Chemical Stability of Pharmaceuticals, A Handbook for Pharmacists, $2^{\text {nd }}$ ed.; Wiley \& 
Sons: New York, 1986, pp. 163-168, 302-318, 377-384, 509-516, 561-565, 650-654.

[9] Eittenmiller, R.R. ;Ye, L.; Landen, W. O. Jr. Chap. 11. In: Vitamin Analysis for the Health and Food Sciences, $2^{\text {nd }}$ ed.; CRC Press: Boca Raton, FL, 2008,

[10] British Pharmacopeia; Her Majesty's Stationary Office: London, Electronic version, 2009.

[11] United State Pharmacopeia 30/Natural Formulary 25, United States Pharmacopeia Convention, Inc.: Rockville, MD, Electronic Version, 2007.

[12] Sweetman, S.C. Ed., Martindale: The Complete Drug Reference, $36^{\text {th }}$ ed.; Pharmaceutical Press: London, Electronic Version, 2009.

[13] Pratt, J.M. The chemistry of vitamin $B_{12}$. Part II. Photochemical reactions. J. Chem. Soc., 1964, 5154-5160.

[14] Vogler, A.; Hirschmann, R.; Otto, H.; Kunkely, H. Photochemistry of biologically important transition metal complexes. I. Cyanocobalamin and related corrin complexes of rhodium (III). Ber. Bunsenges Physik. Chem., 1976, 80, 420-424.

[15] Ahmad, I.; Hussain, W. Stability of cyanocobalamin solutions in sunlight and artificial light. Pak. J. Pharm. Sci., 1993, 6, 23-28.

[16] Ahmad, I.; Hussain, W.; Fareedi, A.A. Photolysis of cyanocobalamin in aqueous solution. J. Pharm. Biomed. Anal., 1992, 10, 9-15.

[17] Ansari, I.A.; Vaid, F. H.M.; Ahmad, I. Chromatographic study of photolysis of aqueous cyanocobalamine solution in presence of vitamin B and C. Pak. J. Pharm. Sci., 2004, 17, 19-24.

[18] Yamada, K.; Shimodaria, M.; Chiada, S.; Yamada, N.; Matsushima, N.; Fukuda, M.; Yamada, S. Degradation of vitamin $\mathrm{B}_{12}$ in dietary supplements. Int. J. Vitam. Nutr. Res., 2008, 28, 195203.

[19] Patel, R.P.; Soni, F.K. Photolysis of cyanocobalamin in the presence of riboflavin. Indian J. Pharm., 1964, 26, 35-37.

[20] Ahmad, I.; Hussain, W. Multicompartment spectrophotometric assay of cyanocobalamin, hydroxocobalamin and riboflavin. Pak. J. Pharm. Sci., 1992, 5, 121-127.

[21] Ahmad, I.; Ansari, I.A.; Ismail, T. Effect of nicotinamide on the photolysis of cyanocobalamin in aqueous solution. J. Pharm. Biomed. Anal., 2003, 31, 369-374.

[22] Akhtar, M.J.; Ataullah, M.; Ahmad, I. Effect of riboflavin on the photolysis of folic acid in aqueous solution. J. Pharm. Biomed. Anal., 2000, 23, 1039-1044.
[23] Ahmad, I.; Vaid, F.H.M. Chap. 2. In: Flavin Photochemistry and Photobiology; Silva, E.; Edward, A.M. Eds.; Royal Society of Chemistry: Cambridge, 2006.

[24] Fall, H.H.; Petring, H.G. Metabolic inhibitors. 1. 6,7-Dimethyl-9formylmethylisoalloxazine, 6, 7-dimethyl-9-(2-hydroxyethly)-isoalloxazine and derivatives. J. Am. Chem. Soc., 1956, 78, 377-381.

[25] Fukumachi, C.; Sakurai, Y. Vitamin $B_{2}$ photolysis. V. The photolytic formation of 6,7-dimethylflavin-9-acetic ester from riboflavin. Vitamins (Kyoto), 1954, 7, 939-943.

[26] Moffat, A.C.; Osselton, M.D.; Widdop, B. Clarke's Analysis of Drugs and Poisons in Pharmaceuticals, Body Fluids and Postmortem Material, $3^{\text {rd }}$ ed.; Pharmaceutical Press: London, 2004, pp. 855,1533 .

[27] Cima, L.; Mantovan, R. Cyanocobalamin and hydroxocobalamin separation by thin layer chromatography. Farmaco (Pavia), Ed. Prat., 1962, 17, 473-481.

[28] Covello, M.; Schettino, O. Chromato-spectrophotometric determination of hydroxo- and cyanocobalamin associated with other medication in various pharmaceuticals. Farmaco (Pavia), Ed. Prat., 1964, 19, 38-51.

[29] Ahmad, I.; Rapson, H.D.C.; Heelis, P.F.; Phillips, G.O. Alkaline hydrolysis of 7, 8-dimethyl-10-(formylmethyl) isoalloxazine. A kinetic study. J. Org. Chem., 1980, 45, 731-733.

[30] Hatchard, C.G.; Parker, C.A. A new sensitive chemical actinometer. II. Potassium ferrioxalate as a standard chemical actinometer. Proc. R. Soc. (Lond.), 1956, A 235, 518-536.

[31] Bayer, J.; Zur spektrophotometrischen untersuchung von cyanound hydroxocobalamin. Pharmazie, 1964, 19, 602-605.

[32] Moore, D.E. Chap. 2. In: Photostability of Drugs and Drug Formulations; Tonnesen, H.H. Ed.; Taylor \& Francis: London, 1996.

[33] Ansari, I.A.; Vaid, F.H.M.; Ahmad, I. Spectral study of photolysis of aqueous cyanocobalamin solutions in presence of vitamin B and C. Pak. J. Pharm. Sci., 2004. 17,93-99.

[34] Hill, J.A.; Pratt, J.M.; Williams, R.J.P. The corphyrins. J. Theor. Biol., 1962, 3, 423-445.

[35] Sunshine, I. CRC Handbook of Spectrophotometric Data of Drugs, CRC Press: Boca Raton, FL, 1981, p. 294. 